\title{
Working Conditions and Employees' Productivity in Cross River State Civil Service, Nigeria
}

\author{
Ipole, Peter A. PhD \\ Okpa, John T. \\ Sociology Department, University of Calabar, \\ Cross River State Civil Service, Nigeria
}

Doi:10.19044/esj.2019.v15n8p132 ～URL:http://dx.doi.org/10.19044/esj.2019.v15n8p132

\begin{abstract}
This study examined the relationship between working conditions and employees' productivity in Cross River State Civil Service, Nigeria. The study specifically examined the relationship between reward system, promotions, and employees' productivity. The research adopted a descriptive survey design. The instrument used for data collection was a questionnaire distributed to nine hundred and twelve (912) staff of Cross River State Civil Service. Data were statistically tested using linear regression statistical technique method. The results show that there is a significant relationship between reward system, promotions, and employees’ productivity.
\end{abstract}

Keywords: Working conditions, employees’ productivity, reward system, \& promotion

\section{Introduction}

Organizations globally, desires to employ and retain workers with 'high pedigree and the potentials of high productivity. Employees' productivity is a function of the type of motivations available in the workplace. Where the working condition is favourable, workers automatically work with enthusiasm and less concern about their welfare, but if it is contrary, workers are disenchanted as their commitment dwindles, and productivity becomes a mirage (Makinde, 2013). The working conditions in which civil servants in Nigeria perform their day-to-day task has left more to be desired (Chipeta, 2014). Most civil servants are unable to perform their duties satisfactorily due to inadequate and poor supply of functional equipment, lack of stationaries, and unsupportive management systems (Edoho, Bamidele, Neji \& Frank, 2015). Lack of a career structure, poor housing, inadequate clinical facilities, drugs (for civil servants in state-owned medical facilities), inadequate pay, lack of recreational facilities, limited schooling opportunities for children, 
academic isolation and bureaucratic problems have also been identified as factors that affect the productivity of civil servants in Nigeria (Edoho, Bamidele, Neji \& Frank, 2015).

According to Akwash (2016) workers are often exposed to poor working conditions, unsatisfactory hygiene environment and facilities, delay and denial of promotions, as well as poor reward system. Other prevalent problems with regards to working conditions in Nigeria Civil Service are inadequate office accommodation, inadequate lighting, poor and epileptic power supply, lack of sufficient ventilation, shortage of working apparatus, routine refusal to pay overtime benefits, unfriendly welfare packages, as well as poor health insurance schemes, which have left most workers taking responsibility for their medical expenses (Igbe, Okpa \& Aniah, 2017; Ipole, Agba, \& Okpa, 2018). It is sad to note that Africa and indeed Nigeria are losing their experienced and seasoned public servants to developed countries as a result of neglect of the public service by government (Ipole, 2018). In Cross River State civil service issues such as understaffing, excessive workload, inadequate supervision or support and long working hours are some of the challenges affecting the productivity of civil servants in the civil service. Other issues include lack of essential working equipment, little or no training for staff, poor rewarding system, delay and denial of promotion, lack of sufficient consumables, among others has been described as factors that have compromised the productivity of civil servants in Cross River State (De Villiers \& De Villiers, 2014; Edoho, Bamidele, Neji \& Frank, 2015; Ipole, Agba, \& Okpa, 2018).

Previous studies (Agba, 2010; Ushie, Agba, \& Agba, 2010; Neji \& Frank, 2015; Igbe, Okpa \& Aniah, 2017; Ukwayi \& Okpa, 2017; Ukwayi, Agba, \& Okpa, 2018; Ipole, Agba, \& Okpa, 2018; Ukwayi, Okpa \& Dike, 2018) have argued that the interplay between conducive working environment and employee productivity, suggest that the formulation and implementation of government policies will be defective, if quality work environment, a satisfied and committed workforce are not developed and placed in their right context for efficient service delivery. These provisions will create a sense of belonging, where every worker feels that he or she is an important stakeholder who must make significant contributions that aim to improve productivity in Cross River State Civil service. This study examined the relationship between working conditions and employee's productivity in Cross River State Civil Service, Nigeria. The study, therefore, hypothesized that there is no significant relationship between reward system, promotion and employees' productivity in Cross River State Civil Service, Nigeria 


\section{Literature review}

\section{Reward system and employees’ productivity}

Organisations generally reward their staff because of the belief that rewarding employees diligently would attract, retain, and motivate workers to better productivity. Therefore, any reward system that fails to achieve these would be considered as an ineffective reward system. Reward system is the total of all financial and non-financial value enjoyed by the employee. This include salaries, benefits, incentives, allowance, fringe benefits, etc; and any other incentives or extensive rewards of employment exchange that an employee expects or value (Jones \& George, 2003). A friendly reward system occupies an important and vital place in the life of any employee and the organisation. Reward system such as prompt payment of allowances and other fringe benefits could positively impact on the moral and productivity of civil servants. When civil servants are substantially and well remunerated, usually they perform effectively in the realm of productivity and promotion of all ethical practices that concerns the organisation.

Oyira, Ella, Nkamare, Lukpata, Uwa and Mbum (2014) carried out a study on the effect of reward system on health care workers performance in University of Calabar Teaching Hospital Calabar, Nigeria. Desk survey was used in gathering relevant information. Primary sources were questionnaire, observation and interview, while secondary data were gathered from internet, textbooks, journals and libraries. Chi-square statistical tool was used, findings revealed that the monetary reward had a positive impact on employees' performance while non-monetary rewards had a negative effect on employees' performance. The study recommended that management of UCTH should boost the morale of their employees through fair and equitable reward system. The study further recommended that management should be effective with monetary rewards like bonuses and fringe benefits to encourage the workers improve performance.

Abdul, Muhammad, Hafiz, Ghazanfar \& Muhammad (2014) studied the impact of compensation on employee performance in Pakistan. The purpose of the research was to measure the impact of compensation on employee performance. A questionnaire was designed to collect the data on the factors related to compensation like salary, rewards, indirect compensation and employee performance. The data was collected from different banks of Pakistan. The data collected were analyzed in SPSS 17.0 Version. Different analytical and descriptive techniques were used to analyze the data. It was found from different results that compensation has positive impact on employee performance. It was proved from correlation analysis that all the independent variables have weak or had moderately positive relationship to each other. Regression analysis showed that all the independent variables have insignificant and positive impact on employee performance. Descriptive 
analysis also revealed that all the independent variables have positive impact on employee performance. ANOVA results revealed that education have not same impact on employee performance.

The effect of salary, training and motivation on job performance of employees was studied by Zahra, Xia, Khuram, Liu \& Amna (2015). They observed that job performance of employees was the area of concern of all the firms no matter whether they stand for profit or for non-profit, so the basic purpose of the research was to identify the effect of important factors like salary, training and motivation on the job performance of the employees in educational sectors as they directly relate with job performance. Sample was taken from the 16 Universities of twin cities of Pakistan i.e., Islamabad and Rawalpindi. Sample size taken for the research was 310. By using regression analysis, findings of the study showed that salary, training and motivation had a positive relationship with job performance but salary has a stronger relationship with job performance than training and motivation. It was recommended that top managers of organizations need a good understanding of the factors that can increase the job performance of the employees which will ultimately increase organizational productivity.

\section{Promotion and employees' productivity}

Promotion is a term referred to as the method through which employees' in an organization are assigned higher responsibility and an increased remuneration after meeting certain standard set of achievements and accomplishments in an establishment. It also means employee upward movement in the work place, culminating to greater task, higher status, and improved pay. According to Heathfield (2011) "promotion is the transfer of an employee to a job which pays more money or one that carries some preferred status." Both employers and employees' benefits from a wellstructured promotion exercise, making promotion crucial to the survival of any organization. Promotion boosts the morale of promoted employees, increases their productivity, encourages competitive spirit at the workplace, and hence improves upon the overall productivity of the establishment. When employees' are well motivated through routine promotion, morale is usually high at work place. This results in high productivity and prevents organisations from losing its valuable and important employees. Comparatively, promotion make more sense to government employees' than staff in corporate organisations. In the government sector, the word promotion is the ultimate desire for an employee for the service rendered by him in the organisation and this is the only way for an employee career development in the government sector. Promotion is the ultimate motivating factor for any employee because it moves an employee forward in hierarchy of concern organisation added with 
additional responsibility, higher respect, honour, with increase in grade pay and allowances.

Mathis and Jackson (2004) noted that productivity is a position resulting from evaluating one's job experiences and rewarding the individual accordingly. Weiss (2002) argues that productivity is an attitude, which describes how content an individual is with their job. Multi-national cooperation's, small organisations, as well as government establishment adopt promotion as a way of motivating their employees to perform better. It is seen as a fair method of rewarding those whose performance is considered exemplary and in the process encourages everyone to strive and perform better (Rupia, Musa, Nandi, \& Odera, 2012).

Nwude and Uduji (2013) conducted a study on how prospect for promotion affects worker productivity in Federal Teaching Hospitals in Nigeria. Cross-sectional survey research design was adopted. A sample of 560 health workers were purposively selected from top fourteen Federal Teaching Hospitals in Nigeria. Test results of the tests of between-subject effects present the model for the relationship between staff performance and other variables and the relationship between staff performance and each of the variables separately. With $\mathrm{F}$ - values at $\mathrm{P}<0.05$, it was revealed that the model relationships are significant. This indicates that on its own, an intense desire for promotion (a very important reward) will motivate a health worker to a greater effort. It was therefore recommended that the Hospital management board should design a career structure, in which promotions are tied to better job performance, and health managers should make every effort to keep the process as objective as possible in the federal teaching hospital in Nigeria.

Daneshkohan, Zarei, Mansouri, Maajani, Ghasemi, and Rezaeian, (2015) carried out a study on factors affecting job motivation among health workers in Iran. The study adopted a cross-sectional survey research design. Two hundred and twelve (212) health workers of Tehran health centers were purposively selected from November and December 2011. The data collection tool was a researcher-developed questionnaire that included 17 motivating factors and 6 demotivating factors and 8 questions to assess the current status of some factors. Data were analysed with descriptive and analytical statistical tests. The main motivating factors for health workers were good management, regular promotion, supervisors, and managers' support and good working relationship with colleagues. On the other hand, unfair treatment, poor management, and lack of appreciation were the main demotivating factors. Strengthening management capacities to regularly promote their staff in the health sector can increase job motivation and improve health workers' performance. The findings suggests that special attention should be paid to some aspects such as management competencies, regular promotion, social 
support in the workplace, treating employees fairly and performance management practices, especially supervision and performance appraisal.

Zahra, Xia, Khuram, Liu, and Amna (2013), conducted a study on the effect of promotion opportunity on job satisfaction among academics in Higher Public Institutions in Malaysia. The result from analysis indicated $\mathrm{r}=$ 0.590, $\mathrm{p}=0.000$ and according to Guildford Rule of Thumb, when $r=0.590$, $\mathrm{p}=0.000$, it showed moderate strong correlation between promotion opportunity and job satisfaction. This result answered the objective, thus confirmed a significant correlation between promotion opportunity and job satisfaction. Result also revealed that, promotion opportunities are also an important aspect of a worker's career and life. It can have a significant impact on other job characteristics such as responsibilities, etc. The university can use promotion opportunities as a reward for highly productive workers to exert greater effort. More satisfied workers are less likely to leave their employer, have lower rates of absenteeism and higher productivity.

\section{Theoretical framework}

\section{Human relations theory}

The human relations theory is attributed to the outcome of the studies, referred to as the Hawthorne experiments, carried out by Elton Mayo (19271932) and his colleagues in the Western Electric Company in Chicago. The tenets of the theory are as follows: firstly, a worker's need for recognition, consultation and a sense of belonging is more important in determining his morals and productivity than the physical ability or stamina. Secondly, noneconomic factors (social rewards and sanctions) are significant determinants of workers' motivation and their levels of job satisfaction. In other words, productivity is strongly affected by social and psychological factors, not simply by conditions of work. Thirdly, informal groups within an organization strongly influence the work habits and attitude of the individual workers. Lastly, an effective style of supervision is created when the managers consult the work groups and their informal leaders before introducing every change in the work schedule. Where all these factors among others are in place, the workers have a sense of belonging and are treated as critical stakeholders in progress (with their own welfare adequately taken care of), then, there is a guarantee that they will put in their best for optimal productivity and organizational growth.

\section{Materials and Methods}

The study adopted a cross-sectional survey design, which involves observations of a sample, or a cross-section of a population or phenomenon that are made at one point in time (Babbie, 2010). The design was adopted because it is used to study people's feelings and perception about social 
phenomenon such as working conditions and employee's productivity (Ukwayi \& Okpa, 2017). The design promotes the utilization of questionnaire in gathering data; this makes it cheaper as compared to other designs (Isangedighi, Joshua, Asim \& Ekuri, 2014). The study was carried out in Cross River State civil service. The population of the study consists of employees of the Cross River State civil service. The total population of the study is seventeen thousand, five hundred and ninety $(17,590)$. The study adopted the multi-stage sampling technique. The sample for the study comprised nine hundred and twelve (912) participants (male and female), which was selected through systematic sampling procedure from the nineteen Ministries, Departments, Parastatals, and Agencies of the Cross River State civil service. The sample comprised personnel, administrative and management staff of the state civil service. A self-designed questionnaire was used for the study. Elicited data were analysed with linear regression analytical procedure.

\section{Ethical consideration}

The researchers got letter of introduction from Sociology Department, which they took to the chairman ethical committee in Cross River State Civil Service; the approved letter from ethics committee chairman was distributed to Commissioners, Permanent secretaries, Heads of Departments, Directors, informing them about the study. The research participants were assured of confidentiality and anonymity in order to ensure honest response from them.

\section{Results \\ Test of Hypotheses \\ Hypothesis one}

Hypothesis one states that, there is no significant relationship between reward system and employees’ productivity of Cross River State Civil Service. Linear regression was conducted to determine the best linear combination between reward system and productivity. The result in Table 1 shows that the predictor variable (reward system) significantly predicted productivity, $\mathrm{F}(1,910)=9.808, \mathrm{P}<.005$. The correlation is positive and small $(\mathrm{R}=.103)$. More importantly, they accounted for 10.3 percent of the variance in productivity. The beta weights suggest that poor rewarding system contribute significantly to the low productivity $(\beta=.103, \mathrm{t}=3.132, \mathrm{p}<.05)$, the adjusted $\mathrm{R}$ Squared value of .010, which is a measure of effect size indicate that 1.0 percent of the variance in rewarding system was explained by the model. This result implies that, the null hypothesis, which states that, there is no significant relationship between reward system and productivity is rejected while the alternate is upheld. 


\section{Hypothesis two}

Hypothesis two states that, there is no significant relationship between promotion and employees’ productivity in Cross River State Civil Service. Linear regression was conducted to determine the best linear combination between promotion and employees’ productivity. The result in Table 2 shows that the predictor variable (promotion) significantly predicted employees' productivity, $\mathrm{F}(1,910)=51.477, \mathrm{P}<$. 05. The correlation is positive and moderate $(\mathrm{R}=.231)$. More importantly, they accounted for 23.1 percent of the variance in employees' productivity. The beta weights suggest that delay and denial of promotion contribute significantly to the prediction of employees' productivity $(\beta=.231, \mathrm{t}=7.175, \mathrm{p}<.05)$, the adjusted $\mathrm{R}$ Squared value of .052 which is a measure of effect size, indicate that 5.2 percent of the variance in employees' productivity was explained by the model. This result implies that, the null hypothesis, which states that, there is no significant relationship between promotion and employees' productivity, is rejected, while the alternate is upheld.

TABLE 1

Linear Regression of Reward System and Employees’ Productivity

\begin{tabular}{|c|c|c|c|c|c|}
\hline Variable & Mean & SD & r-value & Sig. & \\
\hline Reward System & 18.61 & 2.68 & 0.103 & .001 & \\
\hline $\begin{array}{l}\text { Employees' productivity } \\
\text { Model summary }\end{array}$ & 17.36 & 2.53 & & & \\
\hline Model & $\mathrm{R}$ & R Square & $\begin{array}{l}\text { Adjusted } \mathrm{R} \\
\text { Squared }\end{array}$ & $\begin{array}{l}\text { Sd. Error of the } \\
\text { Estimate }\end{array}$ & \\
\hline $\begin{array}{l}1 \\
\text { ANOVA }\end{array}$ & .103 & .011 & .010 & 2.67 & \\
\hline Model & $\begin{array}{l}\text { Sum of } \\
\text { Squares }\end{array}$ & Df & $\begin{array}{l}\text { Mean } \\
\text { Square }\end{array}$ & $\mathrm{F}$ & Sig. \\
\hline Regression & 70.077 & 1 & 70.077 & 9.808 & .002 \\
\hline Residual & 6502.063 & 910 & 7.145 & & \\
\hline Total & 6572.140 & 911 & & & \\
\hline Regression coefficients & & & & & \\
\hline Model & B & Std. Error & Beta & t. & Sig. \\
\hline Constant & 16.715 & .613 & & 27.279 & .000 \\
\hline Employees' productivity & .109 & .035 & .103 & 3.132 & .002 \\
\hline
\end{tabular}


TABLE 2

Linear Regression of Promotion and Employees’ Productivity

\begin{tabular}{|c|c|c|c|c|c|}
\hline Variable & Mean & SD & r-value & Sig. & \\
\hline Promotion & 18.61 & 2.68 & .231 & .000 & \\
\hline Employees’ productivity & 15.32 & 2.86 & & & \\
\hline \multicolumn{6}{|c|}{ Model summary } \\
\hline Model & $\mathrm{R}$ & R Square & $\begin{array}{l}\text { Adjusted } \\
\text { R Squared }\end{array}$ & $\begin{array}{l}\text { Sd. Error } \\
\text { of the } \\
\text { Estimate }\end{array}$ & \\
\hline 1 & .231 & .054 & .052 & 2.614 & \\
\hline Model & $\begin{array}{l}\text { Sum of } \\
\text { Squares }\end{array}$ & Df & $\begin{array}{l}\text { Mean } \\
\text { Square }\end{array}$ & $\mathrm{F}$ & Sig. \\
\hline Regression & 351.871 & 1 & 351.871 & 51.477 & .000 \\
\hline Residual & 6220.269 & 910 & 6.835 & & \\
\hline Total & 6572.140 & 911 & & & \\
\hline \multicolumn{6}{|c|}{ Regression coefficients } \\
\hline Model & B & Std. Error & Beta & $\mathrm{t}$. & Sig. \\
\hline Constant & 15.293 & .471 & & 32.470 & .000 \\
\hline Employees' productivity & .217 & .030 & .231 & 7.175 & .000 \\
\hline
\end{tabular}

\section{Summary of research findings}

(i) There is a significant relationship between reward system and employees' productivity in Cross River State Civil Service.

(ii) There is a significant relationship between promotion and employees' productivity in Cross River State Civil Service.

\section{Conclusion}

Organizations globally, desires to employ and retain workers with high pedigree and productivity. Hence, any organization, demanding the best from their employees' must establish a pleasant working environment in other to bring out the best from their employees' (Pitaloka \& Sofia, 2014). Based on the findings of this study, we therefore conclude that good rewarding system and a carefully planned promotion programme will improve and enhance the productivity of civil servants in Cross River State, Nigeria. The findings of this study is not a surprise as functional reward system and promotion naturally stimulates self-development and builds employees' interest in the job. A friendly reward system occupies an important and vital place in the life of any employee and the organisation. A friendly reward system such as prompt payment of allowances and other fringe benefits could positively impact on the moral and productivity of civil servants. When civil servants are substantially and well remunerated, usually they perform effectively in the realm of productivity and promotion of all ethical practices that concerns the organisation. According to Yoder, Heneman, Turnbull, and Stone (1958), 
"promotion provides incentive to initiative, enterprise, and ambition; minimizes discontent and unrest; attracts capable individuals; necessitates logical training for advancement and forms an effective reward for loyalty, cooperation, and long service” It is against this background that the study recommended that:

(i) Cross River State government through the civil service commission and the office of the Head of civil service should design an enhanced and better rewarding system for all state civil servants. Also, the government should not hesitate to implement the new national minimum wage that will soon be pass into law.

(ii) Government should ensure that workers due for promotion are promoted as-at-when-due. Promotions should only be given on the basis of seniority, hard work, efficiency, attitude, physical fitness, leadership, experience, and length of service and achievement. In addition, implementation of staff promotion should be taking seriously by government.

\section{References:}

1. Abdul, H., Muhammad, R., Hafiz, M. K. Z., Ghazanfar, A., \& Muhammad, A. (2014). Impact of compensation on employee performance (empirical evidence from banking sector of Pakistan). International Journal of Business and Social Science, 5(2), 302-309.

2. Agba A. O. (2010). motivational incentives and staff turnover in the hospitality industry in Cross River State, Nigeria.Global Journal of Management and Business Research. 10 (8),

3. Akwash, F. B. A. (2016). Healthcare transformation: Issues, challenges and the way forward. Worldwide Journal of Multidisciplinary Research and Development, 2(5), 27-30.

4. Babbie, E. (2010). The practice of social research. Belmont, C.A.: Thomson Wadstom.

5. Chipeta, J. B. (2014). Factors that affect staff morale in tertiary hospitals in Malawi: A case study of Kamuzu Central Hospital. Journal of Human Resource and Sustainability Studies, 2, 230-238.

6. Daneshkohan, A., Zarei, E., Mansouri, T., Maajani, K., Ghasemi, M. S. \& Rezaeian, M. (2015). Factors affecting job motivation among health workers: A study from Iran. Global Journal of Health Science. 7(3), 153-160

7. De Villiers, M. R. \& De Villiers, P. J. T. (2014). Doctors' views of working conditions in rural hospitals in the Western Cape. Department of Family Medicine and Primary Care, Faculty of Health Sciences, Stellenbosch University, 46(3), 21-26. 
8. Edoho, S. P., Bamidele, E. O., Neji, O. I. \& Frank, A. E. (2015). Job satisfaction among nurses in public hospitals in Calabar, Cross River State, Nigeria. American Journal of Nursing Science, 4(4), 232-237.

9. Heathfield, S. M. (2011): Promotion is Often a Reward to an Employee for Work Contribution McCelland,

10. Igbe, J.E., J.T. Okpa and E.A. Aniah, 2017. Working conditions and deviant behaviour of employees in the University of Calabar, Cross River State, Nigeria. Journal of Humanities and Social Science, 22(7): 74-83.

11. Ipole, P. A. (2018). Labour migration among skilled workers: A Sociological analysis of existing working conditions in Nigeria. IOSR Journal of humanities and social science. 7 (8), 35-42

12. Ipole, P. A., Agba, A. O. \& Okpa, J. T. (2018). Existing Working Conditions and Labour Unions Agitations in Cross River State Civil Service, Nigeria. Global Journal of Social Sciences Studies

13. . . 4 (1), 39-51

14. Isangedighi, A. J., Joshua, M. T., Asim, A. E and Ekuri, E. E., 2014. Fundamentals of Research and Statistics in Education and Social Science. Calabar: University of Calabar press.

15. Jones, G. R. \& George, J. M. (2003) Contemporary Management, New York: McGraw-Hill.

16. Makinde, H. O. (2013). Securing a harmonious working environment through effective industrial relations at workplace: The Nigerian perspective. Business Management Dynamics, 3(2), 46-59.

17. Mathis, R.L. and Jackson .J.H. (2004). Human Resource Management 4th Edition St Paul: West Publishing Company

18. Nwude, E. C. \& Uduji, J. I. (2013). An analysis of how prospect for promotion affects job performance in the Federal Teaching Hospitals in Nigeria. Public Policy and Administration Research. iiste.org, 3(3), 46-58

19. Oyira, E. J., Ella, R. Nkamare, Felicia, S. E, Lukpata, E., Uwa, S. L., Mbum, P. A. (2015). Effect of reward system among health care workers performance: a case study of university of Calabar teaching hospital Calabar, Nigeria Journal of Hospital Administration 4 (3), 4553

20. Pitaloka, E. \& Sofia, I. P. (2014). The effect of work environment, job satisfaction, organization commitment on OCB of internal auditors. International Journal of Business, Economics and Law, 5(2), 10-18.

21. Rupia, A. S., Musa, G. H., Nandi, O. M. J. \& Odera, O. (2012). Perception of Civil Servants towards Promotion on Merit. American International Journal of Contemporary Research 2 (9), 48-54 
22. Ukwayi, J. K. \& Okpa, J. T. (2017). Critical assessment of Nigeria Criminal Justice System and the perennial problem of awaiting trial in Port Harcourt Maximum prison, Rivers state. Global journal of social sciences $16,17-25$

23. Ukwayi, J. K., Agba, A. M. O., Okpa, J. T. (2018). Working Tools, Acceptance and the Performance of Security Outfits In Niger Delta Region of Nigeria. International Journal of Scientific and Research Publications. 8 (7), 465-474

24. Ukwayi, J. K., Okpa, J. T. \& Dike, E. (2018). Ethnic and Religious Conflict in Jos, Plateau State, Nigeria: A Dangerous Threat to Human Existence and Business Activities. Research on Humanities and Social Sciences 8 (8), 31-37

25. Ushie, E. M., Agba, A. O, Agba, M. S. Chime, J. (2010). leadership style on employees' intrinsic job satisfaction in the Cross River State Newspaper Corporation, Calabar, Nigeria. International Journal of Development and Management Review 5 (1), 61-74

26. Weiss, H.M. (2002). Deconstructing job satisfaction: separating evaluations, beliefs and affective experiences. Human Resource Management Review

27. Yoder, D., Heneman, H. G., Turnbull, J. G., Stone, C. H. (1958). Handbook of personnel management and labor relations New York, McGraw-Hill

28. Zahra, I., Xia, X., Khuram, S., Liu, H., \& Amna, N. (2015). Excellence Training for Productivity; an Empirical Investigation of Pakistani Organizations. American Journal of Business, Economics and Management, 3(2), 29-33. 